\title{
International share portfolio diversification: possible benefits for South African investors
}

\author{
N. Bhana \\ Graduate School of Business, University of Durban Westville, Durban
}

\begin{abstract}
The De Kock Commission has recommended that exchange control regulations be relaxed so that South African investors may acquire foreign securities. The possible gains accruing to South African investors from international share portfolios representing 18 different countries for the period 1969-1983 were investigated. The inclusion of foreign securities results in superior portfolio returns when compared with returns derived from exclusive investment in South African securities.

Furthermore, the South African investor accomplishes significant risk reduction when several foreign countries are included in international portfolios. The returns on South African goldmining shares are negatively correlated with most foreign shares. Therefore, goldmining shares feature prominently in optimal portfolios available to South African investors. By contrast local industrial shares are not included in any of the efficient frontiers. Although the currency factor is important, it was not a major element in the performance and risk components of international portfolios during the study period. The currency factor also constitutes a small percentage of the total risk of an unweighted portfolio representing the $\mathbf{1 8}$ selected countries. The importance of the currency factor is minimized due to low and possibly even negative correlations between share prices and exchange rate movements in the different countries.

S. Afr. J. Bus. Mgmt, 1986, 17: 162-168
\end{abstract}

Die De Kock Kommissie het voorgestel dat valutabeheermaatreëls verslap word sodat beleggers buitelandse sekuriteite kan bekom. Die moontlike opbrengste van internasionale aandeelportefeuljes verteenwoordigend van verskillende lande gedurende die periode 1969-1983, is ondersoek. Die insluiting van buitelandse sekuriteite het beter portefeulje-opbrengste tot gevolg indien dit vergelyk word met opbrengste uit suiwer SuidAfrikaanse beleggings. Die Suid-Afrikaanse belegger verkry boonop betekenisvolle risikovermindering indien verskeie buitelandse beleggings deel vorm van internasionale portefeuljes. Die opbrengste van Suid-Afrikaanse goudaandele toon ' $n$ negatiewe korrelasie met meeste buitelandse aandele. Goudaandele verteenwoordig dus optimale portefeuljes beskikbaar vir Suid-Afrikaanse beleggers. In teenstelling hiermee vorm plaaslike nywerheidsaandele nie deel van enige van die doeltreffende grense nie. Alhoewel die handelskoersfaktor belangrik is, was dit nie gedurende die studietydperk ' $n$ belangrike faktor in die prestasie- en risikokomponente van internasionale portefeuljes nie. Die handelskoersfaktor verteenwoordig ' $n$ klein persentasie van die totale risiko van 'n onbeswaarde portefeulje van die 18 geselekteerde lande. Die belangrikheid van die handelskoersfaktor word verminder deur lae en moontlik selfs negatiewe korrelasies tussen aandeelpryse en handelskoersbewegings in die verskillende lande.

S.-Afr. Tydskr. Bedrytsl. 1986, 17: 162-168

\section{N. Bheng}

Graduate School of Business, University of Durban-Westville, Private Bag X54001, Durban, 4000 Republic of South Africa

Accepted March 1986

\section{Introduction}

The Exchange Control Regulations of 1961, as amended, preclude South African residents from acquiring foreign securities from income derived in South Africa. In recent years major relaxations of the control regulations relating to non-residents have been implemented (Bhana, 1985). The De Kock Commission (1985, p.134) also recommended a progressive relaxation of exchange control over foreign portfolio investments by South African residents. The Commission recommended that initially registered insurers, pension funds, and mutual funds be allowed to invest $10 \%$ of their annual cash inflows in foreign securities approved by the Registrar of Financial Institutions. The De Kock Commission (1985) also recommended that in due course such provisions should be extended to financial institutions and corporate bodies and eventually to individuals and noncorporate bodies. In view of the proposed relaxation of exchange control regulations, it is important to determine if South African investors are likely to benefit from international portfolio diversification.

\section{Research design and Methodology}

In order to demonstrate the range of possible gains to South African investors from international diversification, information on the risk and return on equity capital of 18 countries (including South Africa) have been collected (see Table 1). The foreign countries selected for examination were chosen to satisfy the following criteria: (i) an acceptable level of past political stability; and (ii) reasonable availability of sufficient data to permit the calculation of annual return and risks (adjusted for foreign exchange fluctuations) on industrial share market indices.

Furthermore, the countries chosen for investigation are countries with which South Africa has important trade links and which are therefore suitable candidates for security investments.

For this study, gains or losses from foreign exchange fluctuations were included in the calculation of the returns on assets and were therefore included in the measure of risk. Risks on foreign investments stemming from exchange restrictions and political instability were disregarded. First, these risks cannot be quantified, secondly this study is confined to countries with stable political backgrounds, and thirdly it can be argued that these risks can be expected to be reflected in the prevailing prices of the securities concerned. The study covers the period during which the foreign exchange rates were allowed to 'float'. Therefore, the currency factor is likely to have some impact on the risk- 
returns generated by foreign securities.

The complexity of operating in international financial markets results in different tax structures, exchange controls, exchange risks, and monetary interrelationships. Therefore, no satisfactory asset pricing theory applicable in an international context has been developed. As a result, the risk of an investment cannot be represented by a single risk measure such as domestic or international beta. Therefore, the riskreward optimization principle has been used to construct efficient international portfolios (Markowitz, 1959).

An efficient international portfolio is defined as a combination of investments in various countries which either maximizes the rate of return given the standard deviation, or minimizes the standard deviation given a rate of return. The locus of all such points comprises the efficient curve, with each point on the curve representing a particular combination of investment proportions in various countries. The concept of efficient portfolios can be used to derive optimum portfolios which represents an optimal allocation of assets in various foreign securities.

Given the historical rates of return (1969-1983) it is possible to compute the rates of return and standard deviations of cfficient portfolios which would have accrued to South African investors who purchased foreign securities in specified combinations. From an investor's point of view, the most interesting of these combinations are those securities which for any given risk level maximize the portfolio return. Portfolios which have these characteristics enable the construction of an optimal portfolio from a given set of securities and can be obtained through methods of quadratic programming, for which standard computer algorithms are available.

The share price indices for the respective countries (Standard and Poors 500 index for the United States, Financial Times Index for the United Kingdom, etc.) have been used to determine capital gain or loss. The share price index for each country represents the average change in share prices and is therefore the appropriate measure of capital gain or loss on equity transactions. The dividends received are reinvested in fractional shares at current prices after deducting the withholding taxes applicable to the relevant country. The total gain from equity investment (capital gain and dividend yield) has been adjusted for changes in foreign exchange rates between South Africa and the country of investment. As a result, the rates of return used in this study are the relevant rates obtained in South African currency. A general expression for the calculation of the rate of return on a foreign investment which makes adjustments for possible changes in currency fluctuations is:

$R=\left(\frac{D_{1}+P_{1}}{P_{0}} \times \frac{F_{1}}{F_{0}}\right)-1$

where $R=$ rate of return of foreign investment; $D_{1}=$ annual dividend yield in the foreign currency; $P_{0}=$ beginning price of the foreign security in foreign currency; $P_{1}=$ ending price of the foreign security in foreign currency; $F_{1}=$ ending price of foreign currency in terms of the South African rand; and $F_{0}=$ beginning price of foreign currency in terms of the South African rand.

\section{The risk-return trade-off from international portfolio diversification}

In order to demonstrate the possible benefits to a South African investor from international portfolio diversification,
Table 1 Rates of return, standard deviations, and coefficient of correlations of equity investments for 18 selected countries during 1969-1983

\begin{tabular}{|c|c|c|c|c|}
\hline \multirow[b]{2}{*}{ Country } & \multirow{2}{*}{$\begin{array}{c}\text { Compound } \\
\text { annual return } \\
\% \\
(1) \\
\end{array}$} & \multirow{2}{*}{$\begin{array}{c}\text { Standard } \\
\text { deviation } \\
\% \\
(2) \\
\end{array}$} & \multicolumn{2}{|c|}{$\begin{array}{l}\text { Correlation }(R) \text { with } \\
\text { South Africa }\end{array}$} \\
\hline & & & $\begin{array}{l}\text { Industrial } \\
\text { shares } \\
\text { (3) }\end{array}$ & $\begin{array}{l}\text { goldmining } \\
\text { shares } \\
\text { (4) }\end{array}$ \\
\hline Australia & 10,84 & 20,06 & 0,7055 & 0,0795 \\
\hline Austria & 9,19 & 14,63 & 0,0346 & 0,1471 \\
\hline Canada & 14,07 & 18,48 & 0,6718 & 0,1589 \\
\hline Denmark & 20,80 & 29,15 & 0,1445 & $-0,3204$ \\
\hline France & 7,24 & 21,24 & 0,3904 & 0,0021 \\
\hline Finland & 20,54 & 20,45 & 0,1609 & 0,1304 \\
\hline Germany & 15,14 & 17,07 & 0,0882 & $-0,5326$ \\
\hline Italy & 0,06 & 16,35 & 0,5606 & 0,2970 \\
\hline Japan & 25,60 & 21,99 & 0,1432 & $-0,3562$ \\
\hline Netherlands & 11,97 & 14,91 & 0,1441 & $-0,4383$ \\
\hline New Zealand & 12,11 & 15,61 & 0,4385 & $-0,1048$ \\
\hline Norway & 12,77 & 24,25 & 0,3742 & 0,2774 \\
\hline $\begin{array}{l}\text { South Africa } \\
\text { industrial shares }\end{array}$ & 11,17 & 21,43 & 1,0000 & 0,4800 \\
\hline $\begin{array}{l}\text { South Africa } \\
\text { goldmining shares }\end{array}$ & 22,45 & 50,17 & 0,4800 & 1,0000 \\
\hline Spain & 1,97 & 21,48 & $-0,1117$ & 0,0773 \\
\hline Sweden & 18,08 & 20,52 & 0,1534 & 0,0125 \\
\hline Switzerland & 16,10 & 18,32 & 0,2698 & $-0,4242$ \\
\hline United Kingdom & 13,11 & 22,35 & 0,2127 & $-0,4548$ \\
\hline U.S. of America & 12,18 & 18,76 & 0,2195 & $-0,3329$ \\
\hline Average & 13,44 & 19,74 & 0,32 & $-0,02$ \\
\hline
\end{tabular}

the rates of return and risk represented by the standard deviation were calculated for share investments in 18 major industrialized countries during the period 1969-1983. A matrix of correlation coefficients among the annual rate of return of the 18 countries investigated was calculated and the variances and covariances were used in all subsequent calculations. These results are shown in Table 1.

The annual rate of return on equity investments ranged from a high of $25,6 \%$ for Japan to a low of $0,06 \%$ for Italy. The average annual rate of return for all 18 countries is $13,44 \%$, which is slightly higher than the returns on South African industrial shares. However, the average annual returns on South African goldmining shares are substantially higher than the average returns for all 18 countries. The inter-country differences in risk (standard deviations) also varied considerably, South African goldmining shares having had the highest standard deviation of $50,17 \%$ whereas Austria had the lowest standard deviation of $14,63 \%$. Of particular interest is the low correlation of returns among the different countries. Despite the relatively poor performance of the local industrial shares, South African investors may still benefit from international diversification because of the low average correlation of returns $(0,32)$ with the other overseas countries.

South African goldmining shares offer unique opportunities for those seeking international portfolio diversification because of the low average correlation of returns $(-0,02)$ with the overseas countries. In fact these shares are negatively correlated with eight of the 18 countries included in the study. Despite the relatively good performance of the South African goldmining shares, local investors can benefit further from investing in foreign securities. The inclusion of 
foreign securities in a portfolio of South African goldmining shares is likely to reduce substantially the relatively high $(50,17 \%)$ standard deviation of the latter category of shares. It has been shown that as long as the correlation of returns among the different investment options is not perfect (less

Table2 Risk and returns (in local currencies) from international portfolio diversification in 18 selected countries during 1969-1983

\begin{tabular}{|c|c|c|c|c|}
\hline Country & $\begin{array}{l}\text { Domestic } \\
\text { return } \\
\text { per annum } \\
(\%)\end{array}$ & $\begin{array}{c}\text { Ranking } \\
\text { of } \\
\text { return }\end{array}$ & $\begin{array}{c}\text { Domestic risk } \\
\text { per annum } \\
(\%)\end{array}$ & $\begin{array}{c}\text { Ranking } \\
\text { of } \\
\text { risk }\end{array}$ \\
\hline Australia & 9,20 & 11 & 17,83 & 10 \\
\hline Austria & 8,10 & 14 & 12,54 & 19 \\
\hline Canada & 11,85 & 7 & 16,51 & 12 \\
\hline Denmark & 18,93 & 2 & 26,75 & 2 \\
\hline France & 7,21 & 16 & 17,94 & 9 \\
\hline Finland & 17,92 & 4 & 18,53 & 7 \\
\hline Germany & 8,55 & 13 & 13,51 & 16 \\
\hline Italy & 3,49 & 19 & 14,31 & 15 \\
\hline Japan & 18,44 & 3 & 18,56 & 6 \\
\hline Netherlands & 7,09 & 17 & 13,19 & 17 \\
\hline New Zealand & 10,32 & 9 & 12,93 & 18 \\
\hline Norway & 9,73 & 10 & 22,29 & 3 \\
\hline \multicolumn{5}{|l|}{ South Africa } \\
\hline (industrial shares) & 11,17 & 8 & 21,43 & 4 \\
\hline \multicolumn{5}{|l|}{ South Africa } \\
\hline (goldmining shares) & 22,45 & 1 & 50,17 & 1 \\
\hline Spain & 5,11 & 18 & 18,50 & 8 \\
\hline Sweden & 17,78 & 5 & 17,65 & 11 \\
\hline Switzerland & 7,51 & 15 & 14,92 & 14 \\
\hline United Kingdom & 13,25 & 6 & 19,33 & 5 \\
\hline U.S. of America & 8,98 & 12 & 16,06 & 13 \\
\hline
\end{tabular}

than 1) a sufficient, but not necessary condition exists in portfolio diversification (Markowitz, 1959). It can therefore be concluded that even relatively low-return foreig securities may materially reduce the risk of an international diversified portfolio held by South African investors.

In order to determine the role played by foreign currencien in the risk-return characteristics of an intemationally diversified portfolio a more detailed analysis of the empirioa results is necessary. Table 2 contains the performance and volatility figures for the 18 countries in local currencies for the period 1969-1983.

The performance and risk measures in Table 2 are pressed in the currency prevailing in the country where the market is located. The domestic risk is defined as the standard deviation of the annual domestic returns over the 1969-1983 period. From the ranking of the domestic annual returns it can be seen that the best returns during the study period have been attained by South African goldmining shares, Denmark, Japan, and Finland. However, these countries also have the largest risk, as can be seen from the rankings of the domestic risk. It is noteworthy that South African industrial shares have a relatively high domestic nisk but only average domestic returns. This observation is further confirmation of the benefits accruing to South African investors from international portfolio diversification.

The risk-return characteristics represented in Table 2 are expressed in the domestic currency where the investment is made. However, South African investors are more concemed with the performance of their foreign investments expressed in South African currency. Therefore, the figures in Table 3 are the risk-return characteristics of investments expressed in rands.

The total risk is defined as the standard deviation of the annual returns of each country expressed in South African rands during the period 1969-1983. The exchange risk is

Table 3 Risk and returns (in South African rands) from international portfolio diversification in 18 selected countries during 1969-1983

\begin{tabular}{|c|c|c|c|c|c|c|c|}
\hline Country & $\begin{array}{l}\text { Compound } \\
\text { annual retum } \\
\text { (1) }\end{array}$ & $\begin{array}{c}\text { Ranking } \\
\text { of annual } \\
\text { retum } \\
(2) \\
\end{array}$ & $\begin{array}{c}\text { Exchange } \\
\text { gain or (Loss) } \\
(3)\end{array}$ & $\begin{array}{c}\text { Total risk } \\
\text { (RSA rands) } \\
(4)\end{array}$ & $\begin{array}{c}\text { Ranking of } \\
\text { total risk } \\
(5)\end{array}$ & $\begin{array}{c}\text { Domestic } \\
\text { risk } \\
(6) \\
\end{array}$ & $\begin{array}{c}\text { Exchange } \\
\text { rist } \\
(7) \\
\end{array}$ \\
\hline Australia & 10,84 & 15 & 1,64 & 20,06 & 11 & 17,83 & 9,75 \\
\hline Austria & 9,19 & 16 & 1,09 & 14,63 & 19 & 12,54 & 8,36 \\
\hline Canada & 14,07 & 8 & 2,22 & 18,48 & 13 & 16,51 & 9,08 \\
\hline Denmark & 20,80 & 3 & 1,87 & 29,15 & 2 & 26,75 & 11,16 \\
\hline France & 7,24 & 17 & 0,03 & 21,24 & 8 & 17,94 & 8,75 \\
\hline Finland & 20,54 & 4 & 2,62 & 20,45 & 10 & 18,53 & 9,45 \\
\hline Germany & 15,14 & 7 & 6,59 & 17,07 & 15 & 13,51 & 11,48 \\
\hline Italy & 0,06 & 19 & $(3,43)$ & 16,35 & 16 & 14,31 & 7,98 \\
\hline Japan & 25,60 & 1 & 7,16 & 21,98 & 5 & 18,56 & 11,27 \\
\hline Netherlands & 11,97 & 13 & 4,88 & 14,91 & 18 & 13,19 & 10,24 \\
\hline New Zealand & 12,11 & 12 & 1,79 & 15,61 & 17 & 12,93 & 10,51 \\
\hline Norway & 12,77 & 10 & 3,04 & 24,25 & 3 & 22,29 & 8,27 \\
\hline \multicolumn{8}{|l|}{$\begin{array}{l}\text { South Africa } \\
\text { (industrial sharec) }\end{array}$} \\
\hline $\begin{array}{l}\text { (industrial shares) } \\
\text { South Africa }\end{array}$ & \multicolumn{7}{|c|}{ South Africa } \\
\hline (goldmining shares) & 22,45 & 2 & - & 50,17 & 1 & 50,17 & - \\
\hline Spain & 1,97 & 18 & $(3,14)$ & 21,48 & 6 & 18,50 & 9,64 \\
\hline Sweden & 18,08 & 5 & 0,30 & 20,52 & 9 & 17,65 & 9,19 \\
\hline Switzerland & 16,10 & 6 & 8,59 & 18,32 & 14 & 14,92 & 13,25 \\
\hline United Kingdom & 13,11 & 9 & $(0,14)$ & 22,35 & 4 & 19,33 & 9,33 \\
\hline U.S. of America & 12,18 & 11 & 3,20 & 18,76 & 12 & 16,06 & 10,22 \\
\hline & & & & & & $10, \infty$ & \\
\hline Average & 13,44 & & 2,25 & 21,43 & & 19,10 & 9,88 \\
\hline
\end{tabular}


defined as the standard deviation of the annual returns of exchange rates in the different countries (expressed as a percentage per annum). The exchange gain (or loss) is defined as the percentage return per annum of the respective currencies of the various countries being investigated. The exchange gain (or loss) reflects the extent to which the various foreign currencies have moved in relation to the South African currency during the 1969-1983 period. The South African rand appreciated in value against the currencies of Italy, Spain, and the United Kingdom (indicating an exchange loss for the South African investor). For the remaining countries the South African rand depreciated in value against their currencies (indicating an exchange gain for the South African investor).

In Table 3 it is shown that the exchange gain or loss from foreign investments has had a significant influence on investment performance. As a result of a substantial foreign exchange gain from investing in Japan, investing in this country has replaced investing in goldmining shares as the best return available to local investors. It is also interesting to observe that exchange gains have reduced the relative attractivencss of investing in South African industrial shares (ranking of returns lowered from position 8 to position 14). As a result of exchange risk (column 7), the total risk (column 4) of investing in all foreign countries is higher than the domestic risk (column 6) in the respective countries. As a result of this, the risk ranking of South African industrial shares has improved from position 4 (Table 2) to position 7 (Table 3). Therefore, the currency factor has had an important influence on both risk and returns associated with international portfolio diversification. The results in Table 3 indicate that the exchange gains from the various foreign currencies have generally enhanced the attractiveness of investing in foreign securities from the point of view of a South African investor.

It can also be seen from Table 3 that the differential between the risk in South African rands (column 4) and the risk in domestic currencies (column 6) is generally smaller than the exchange risk (column 7). Solnik \& Noetzlin (1982) showed that this is due to the low and possibly even negative correlation between security prices and exchange rate movements. This leads to an important observation that foreign securities that are attractive to a South African investor may not necessarily be desirable to an investor in another country whose base currency is say, United States dollars or British pounds. Therefore, optimal international portfolios will vary from one country to another, depending on the risk-return characteristics as well as exchange rate movements in the different countries.

Although the currency factor is important it is not a major element in the performance and risk components of an internationally diversified portfolio representing the 18 countries investigated during 1969-1983. This can be seen clearly from the data presented in Table 3 . The overall impact of exchange gains or losses on investment returns can only be judged in relation to a specific internationally diversified portfolio. It can be seen from Table 3 that the overall exchange gains enhanced the average annual total returns of a unweighted international portfolio by $2,25 \%$, which amounts to $16,74 \%$ of the average total return over the 1969-1983 period. Therefore, the currency factor has not been a major component of total return even though the South African rand was generally devalued against the other currencies during the study period.

It can also be seen from Table 3 that the total risk (column
4) is less than the sum total of the domestic risk (column 6) and exchange risk (column 7). This is because there usually is a weak or possibly a negative correlation between currency and domestic risk. The exchange risk as a component of the total risk attached to a foreign investment also requires to be analysed further, and these data are presented in Table 4.

In Table 4 the risk of a foreign investment in South African rands (column 1), risk in domestic currency (column 2 ), and the resulting differential or portion of risk that can be ascribed to the currency factor (column 3) are shown. Currency risk averaged $2,59 \%$ and amounts to $13,1 \%$ of the total risk involved in an unweighted portfolio investment comprising the 18 selected countries. As in the case of returns, the aggregate impact of the currency factor on the total risk can only be evaluated in terms of a specific internationally diversified portfolio. Nevertheless, the results suggest that exchange risk make up only a small amount of aggregate investment risk of an internationally diversified portfolio.

Table 4 Profile of currency factor in total investment risk for 18 selected countries during 1969-1983

\begin{tabular}{|c|c|c|c|}
\hline Country & $\begin{array}{c}\text { Total } \\
\text { risk in } \\
\text { RSA rands } \\
\text { (1) }\end{array}$ & $\begin{array}{l}\text { Risk in } \\
\text { domestic } \\
\text { currency } \\
(2)\end{array}$ & $\begin{array}{c}\text { Risk } \\
\text { differential } \\
\text { (currency } \\
\text { factor) } \\
\text { (3) } \\
(1)-(2)\end{array}$ \\
\hline Australia & 20,06 & 17,83 & 2,23 \\
\hline Austria & 14,62 & 12,54 & 2,09 \\
\hline Canada & 18,48 & 16,51 & 1,97 \\
\hline Denmark & 29,15 & 26,75 & 2,30 \\
\hline France & 21,24 & 17,94 & 3,30 \\
\hline Finland & 20,45 & 18,53 & 1,92 \\
\hline Germany & 17,07 & 13,51 & 3,56 \\
\hline Italy & 16,35 & 14,31 & 2,04 \\
\hline Japan & 21,98 & 18,56 & 3,42 \\
\hline Netherlands & 14,91 & 13,19 & 1,72 \\
\hline New Zealand & 15,61 & 12,93 & 2,68 \\
\hline Norway & 24,25 & 22,29 & 1,96 \\
\hline $\begin{array}{l}\text { South Africa } \\
\text { (industrial shares) }\end{array}$ & 21,43 & 21,43 & - \\
\hline $\begin{array}{l}\text { South Africa } \\
\text { (goldmining shares) }\end{array}$ & 50,17 & 50,17 & - \\
\hline Spain & 21,48 & 18,50 & 2,98 \\
\hline Sweden & 20,52 & 17,65 & 2,87 \\
\hline Switzerland & 18,32 & 14,92 & 3,40 \\
\hline United Kingdom & 22,35 & 19,33 & 3,02 \\
\hline U.S. of America & 18,76 & 16,06 & 2,70 \\
\hline Average & 21,43 & 19,10 & 2,59 \\
\hline
\end{tabular}

\section{Optimal allocation of assets in efficient international portfolios}

In recent years portfolio managers have devoted much attention to efficient allocation of funds so that the best riskreturn trade-off is obtained. The asset allocation decision is a particularly important and potentially profitable aspect of managing international portfolios because the major markets are not synchronized (Solnik \& Noetzlin, 1982). The technique of constructing efficient portfolios for the optimal allocation of funds for portfolio investment has become standard practice for large institutional investors. The 
optimal portfolio computer program used for this study considered portfolios on the efficient frontier with positive investment constraint (no short selling). One of the major difficulties in allocating funds for portfolio diversification is that mean returns may turn out to be negative (Fung, 1979). This can cause serious distortions in the construction of optimal portfolios if the observed mean returns are taken to be the proxy for expected returns. A sufficient condition for there being benefits from international diversification is that the minimum risk portfolio should contain at least two nonzero investment proportions (Yallup, 1982).

The efficient frontiers for the case in which investments can be made in all 18 countries included in this study are presented in Figures 1 to 5 . The curve labelled E, summarizes the efficient risk-return combinations which were attainable to an investor who had owned an internationally diversified portfolio of equity shares. However, to determine the proportion of investment in each of the various countries, we must choose the optimal portfolio. This can be accomplished by using the market equilibrium model developed by Lintner (1965) and Sharpe (1964). The market opportunity line is represented by $r_{1}$, this line rises from the intercept on the $X$ axis which reflects the risk-free rate of return. The average risk-free rate of return during the study period was $10 \%$. The optimum unlevered portfolio for a particular riskfree rate is given by the point at which the appropriate market opportunity line is tangent to the locus of efficient portfolios, i.e. point $a$ in Figures 1 to 5 .

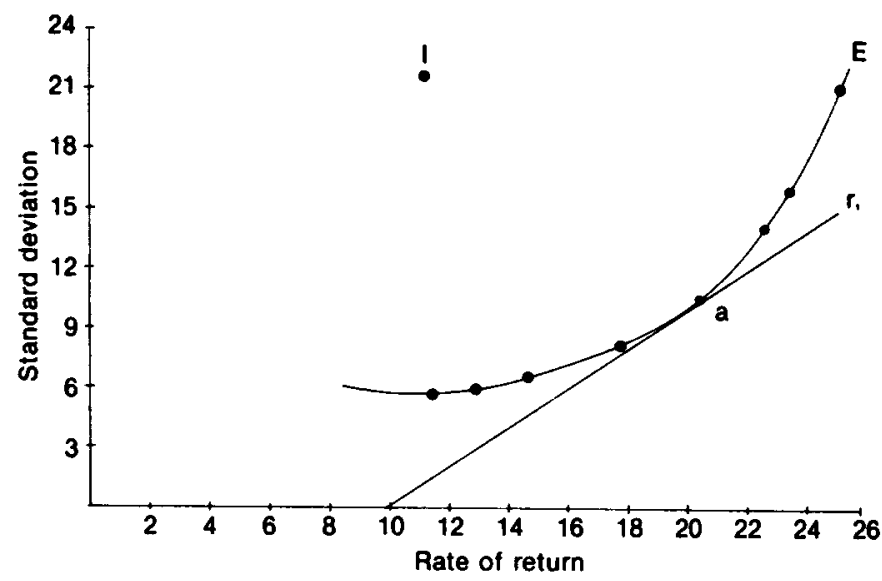

Figure 1 Efficient portfolios available from international diversification (no limit to investment in specific country)

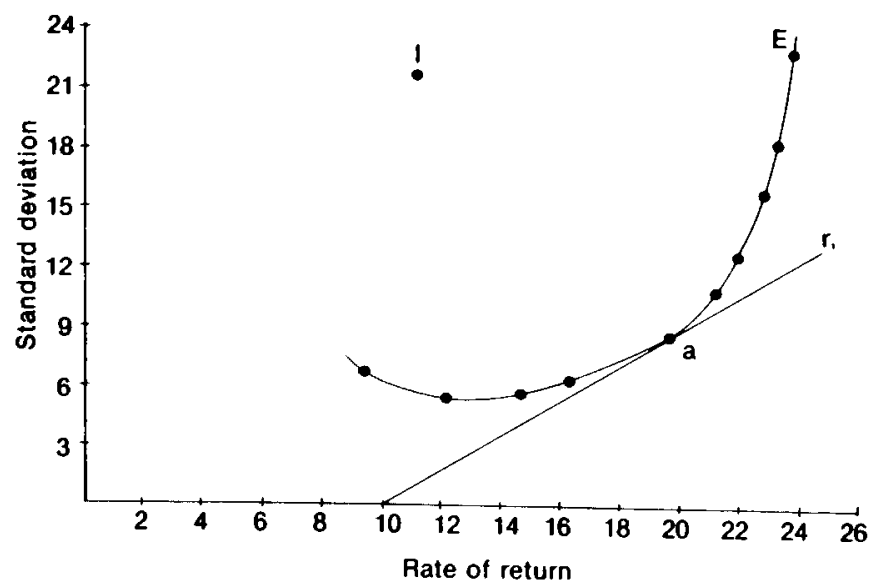

Figure 2 Efficient portfolios available from international diversification (50\% limit to investment in specific country)

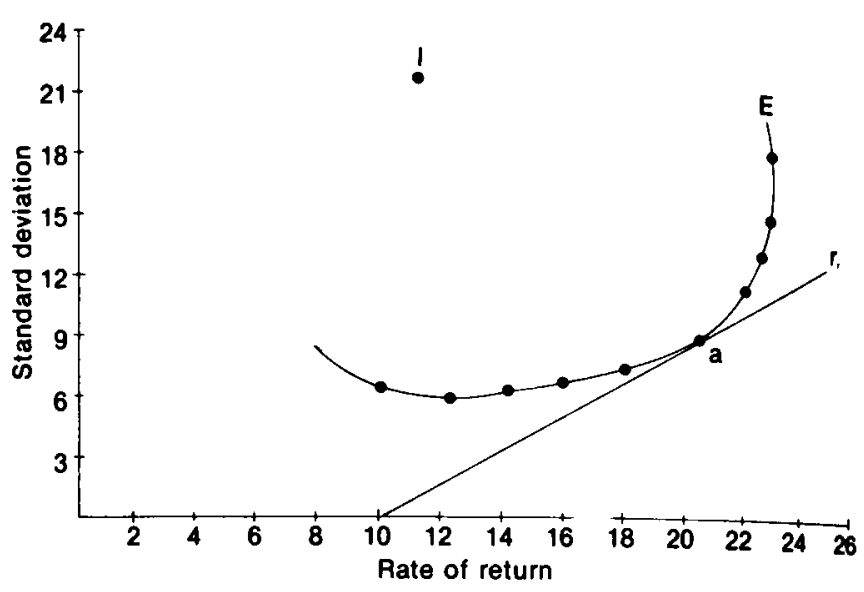

Figure 3 Efficient portfolios available from international diversification (33\% limit to investment in specific country)

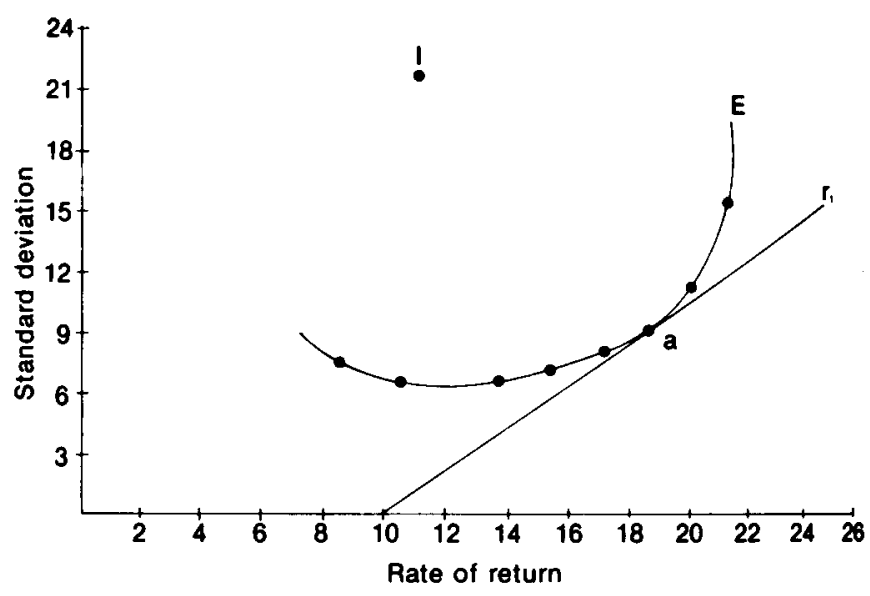

Figure 4 Efficient portfolios available from international diversification (20\% limit to investment in specific country)

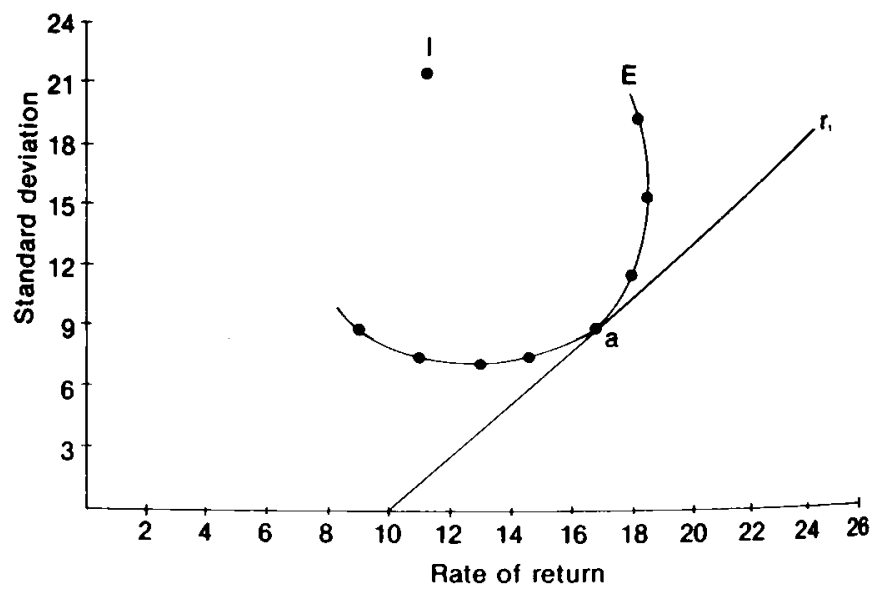

Figure 5 Efficient portfolios available from international diversification (10\% limit to investment in specific country)

In Table 5 the investment proportions for five such optimal portfolios are specified, i.e. no limit, $50,33,20$, and $10 \%$ limit to investment in a single country. The five optimum portfolios shown are in each case the so-called corner portfolios, i.e. those for which further reduction in variance can be achieved through the inclusion or omission of additional securities. The rates of return and standard deviations for the corner portfolios are shown in the last two rows of Table 5 . The other attainable combinations of return and standard deviations can he found bv interpolation 
Table 5 Composition of optimal international portfolios for various levels of maximum investment in specific countries $1969-1983$ (risk-free rate of return $=10 \%$

\begin{tabular}{|c|c|c|c|c|c|}
\hline Country & $\begin{array}{c}\text { No } \\
\text { limit }\end{array}$ & $\begin{array}{l}50 \% \\
\text { limit }\end{array}$ & $\begin{array}{l}33 \% \\
\text { limit }\end{array}$ & $\begin{array}{l}20 \% \\
\text { limit }\end{array}$ & $\begin{array}{l}10 \% \\
\text { limit }\end{array}$ \\
\hline Australia & & & & & 3,52 \\
\hline Austria & & 1,18 & & 2,99 & 10,00 \\
\hline Denmark & & & & & 5,34 \\
\hline Finland & 17,03 & 16,20 & 18,77 & 15,74 & 10,00 \\
\hline Germany & & & & 9,82 & 10,00 \\
\hline Japan & 40,84 & 39,80 & 33,00 & 20,00 & 10,00 \\
\hline New Zealand & & 1,05 & 0,62 & 7,56 & 10,00 \\
\hline Norway & & & & & 1,14 \\
\hline \multicolumn{6}{|l|}{ South Africa } \\
\hline (goldmining shares) & 14,15 & 13,89 & 13,66 & 12,72 & 10,00 \\
\hline Sweden & 11,59 & 11,50 & 12,61 & 11,17 & 10,00 \\
\hline Switzerland & 16,39 & 16,38 & 21,34 & 20,00 & 10,00 \\
\hline United Kingdom & & & & & 10,00 \\
\hline Portfolio return & 21,90 & 21,58 & 21,16 & 19,12 & 16,86 \\
\hline \multicolumn{6}{|l|}{ Portfolio standard } \\
\hline deviation & 12,50 & 12,24 & 11,90 & 10,30 & 9,31 \\
\hline
\end{tabular}

between the corner portfolios, as is done by lines drawn between the points in Figures 1 to 5 . Although 18 countries are investigated in this study, only 12 countries are included in at least one of the optimal portfolios, and Norway can be ignored because a negligible proportion of one of the portfolios is invested in this country. Investments in Japan, Switzerland, Finland, and South African golmining shares account for the majority (40-88\%) of the various optimal portfolios. Canada, France, Italy, South African industrial shares, Spain, and the United States are excluded from all optimal portfolios.

An explanation of these results can best be seen by setting out a correlation matrix for the countries which are included in at least one optimal portfolio (Table 6). Japan, which taken by itself is characterized by a high return and also a high level of risk, has a relatively large share in optimal portfolios owing to generally low covariances with other countries in the efficient set. The return on Japanese investments is negatively correlated with three countries, whilst having low positive correlations with the remaining eight countries. Therefore, despite Japan's relatively high standard deviation, because of covariance, its inclusion tends to reduce the risk of the overall portfolio. This is especially true because the investment returns of Japan are negatively correlated with those of South African goldmining shares, and the latter comprises a fairly large share of all the optimal portfolios. South African goldmining shares, on the other hand, become part of the optimal portfolios on their own merits, these shares having both a very high rate of return and a very high risk level. However, the return on South African goldmining shares is negatively correlated with six countries, whereas the correlation with the remaining five countries is close to zero.

Institutional investors in South Africa have traditionally made large investments in both goldmining and industrial shares. Therefore, it is interesting to note the absence of South African industrial shares from the optimal portfolios. The main reason stems from the industrial shares having a high positive correlation $(0,48)$ with goldmining shares, combined with the fact that the rate of return on industrial shares was much lower than that for goldmining shares. As a result, goldmining shares dominate industrial shares and the latter was eliminated from the efficiency curve in the relevant range. Furthermore, the industrial shares of Japan, Switzerland, Sweden, and Finland have superior risk-return characteristics in comparison with South African industrial shares, and these countries also have negative or only slightly positive correlations with South African goldmining shares.

The potential gains from international portfolio diversification can be seen more clearly by examining Figures 1 to 5 which represent optimal portfolios for different maximum proportions that may be invested in specific countries. The risk-return combinations for portfolios of South African industrial shares are represented by point I. Clearly, investors will suffer losses if they must restrict their portfolios to South African industrial shares only (point I does not lie on the efficient frontier). Diversification among foreign securities and South African goldmining shares would have permitted investors to attain higher rates of return and lower risk of their portfolios than they could have by purchasing a portfolio consisting of South African industrial shares only.

Which combination of securities a South African investor would in fact have chosen cannot be known, because it depends on their individual marginal rate of substitution between risk and return. However, it can be clearly stated that, if an investor wanted to maintain the same variability in return associated with South African industrial shares, international diversification would have permitted him to earn $25,55 \%$ as against $11,17 \%$, a gain of $128,7 \%$ in the

Table6 Inter-country correlation coefficients for countries included in optimal investment portfolios

\begin{tabular}{|c|c|c|c|c|c|c|c|c|c|c|c|c|}
\hline Country & 1 & 2 & 3 & 4 & 5 & 6 & 7 & 8 & 9 & 10 & 11 & 12 \\
\hline \multicolumn{13}{|l|}{ 1. South Africa } \\
\hline goldmining shares & 1,000 & 0,079 & 0,147 & $-0,320$ & 0,130 & $-0,532$ & $-0,356$ & $-0,104$ & 0,277 & 0,012 & $-0,424$ & $-0,454$ \\
\hline 2. Australia & & 1,000 & $-0,279$ & 0,187 & $-0,082$ & 0,035 & 0,254 & 0,585 & 0,304 & 0,093 & 0,306 & 0,350 \\
\hline 3. Austria & & & 1,000 & 0,091 & 0,260 & $-0,053$ & $-0,100$ & $-0,263$ & 0,242 & $-0,157$ & $-0,039$ & $-0,171$ \\
\hline 4. Denmark & & & & 1,000 & 0,483 & 0,566 & 0,621 & 0,460 & 0,293 & 0,502 & 0,400 & 0,229 \\
\hline 5. Finland & & & & & 1,000 & 0,177 & 0,206 & 0,436 & 0,697 & 0,141 & 0,109 & $-0,078$ \\
\hline 6. Germany & & & & & & 1,000 & 0,552 & 0,016 & $-0,143$ & 0,399 & 0,876 & 0,673 \\
\hline 7. Japan & & & & & & & 1,000 & 0,199 & $-0,052$ & 0,210 & 0,539 & 0,494 \\
\hline 8. New Zealand & & & & & & & & 1,000 & 0,545 & 0,116 & 0,082 & 0,027 \\
\hline 9. Norway & & & & & & & & & 1,000 & 0,032 & 0,036 & $-0,256$ \\
\hline 10. Sweden & & & & & & & & & & 1,000 & 0,228 & 0,204 \\
\hline 11. Switzerland & & & & & & & & & & & 1,000 & 0,698 \\
\hline 12. United Kingdom & & & & & & & & & & & & 1,000 \\
\hline
\end{tabular}


annual rate of return (Figure 1). Analogous calculations can be carried out to demonstrate the reduction in risk attainable by internationally diversified portfolios with the same expected rate of return as that from investing in South African industrial shares alone. An inspection of Figure 1 shows that risk can be reduced from $21,43 \%$ to $5,7 \%$, a reduction of $73,4 \%$ in the annual standard deviation.

Because of the high risk associated with investing in South African goldmining shares, the standard deviation does not fall in the range plotted in Figures 1 to 5 . Nevertheless, because of the high risk, investing in South African goldmining shares alone is unlikely to produce optimal investment performance for a local investor. It is only when the South African investor diversifies his portfolio to include countries such as Japan, Sweden, Switzerland, and Finland that a significant improvement in portfolio performance (reduction of risk) results. The systematic nature of risk reduction through international diversification is reflected in the continuous reduction of portfolio risk at all levels of return as the number of foreign countries are increased. It can be seen from Table 5 that when the number of countries in optimal portfolios is increased from five to twelve, the standard deviation is lowered from $12,5 \%$ to $9,31 \%$.

\section{Conclusion}

The results of this study indicate that a South African investor would have improved the risk-return characteristics of his investment by pursuing international diversification during the period 1969-1983. Firstly, the inclusion of foreign securities resulted in superior portfolio returns when compared with returns derived from exclusive investment in South African securities. Furthermore, the exchange gains from various foreign currencies generally enhanced the attractiveness of investing in foreign securities from the point of view of a South African investor. Secondly, the South African investor is able to accomplish significant risk reduction when countries such as Japan, Sweden, Switzerland, and Finland are included in international portfolios.
South African goldmining shares feature prominently in optimal portfolios available to South African investors, whereas local industrial shares are not included in any of the efficient frontiers available to local investors.

Although the currency factor is important, it was not a major element in the performance and risk components of international portfolios representing the 18 countries during 1969-1983. It was observed that fluctuations in exchange rates did not have a material effect on total return even though the South African currency was generally devalued against other currencies during the study period. Furthermore, it was also shown that currency risk constitutes a small percentage of the total risk in an unweighted portfolio investment comprising the 18 selected countries. The importance of the currency factor is minimized due to low and possibly even negative correlations between security prices and exchange rate movements in the different countries.

\section{References}

Bhana, N. 1985. The recommendations of the De Kock Commission of Inquiry and its implications for foreign security investments by South African residents. S. Afr. J. Bus. Mgmt. vol.16, 204-208.

De Kock Commission. 1985. The Commission of Inquiry into the Monetary System and Monetary Policy in South Africa, Final Report, RP 70/1984. Pretoria: Government Printer.

Fung, W.K.H. 1979. Gains from international portfolio diversification: a comment. J. Bus. Fin. Acc. vol.6, 45-49.

Lintner, J. 1965. The Valuation of Risk Assets and the Selection of Risky Investments in Stock Portfolios and Capital Budgets. Rev. Econ. Stat., vol.47, 13-37.

Markowitz, H.M. 1959. Portfolio Selection, Efficient Diversification of Investments. New York: John Wiley and Sons, Inc.

Sharpe, W.F. 1964. Capital Asset Prices: A Theory of Market Equilibrium under Conditions of Risk. J. Fin., vol.19, 425-442.

Solnik, B. \& Noetzlin, B. 1982. Optimal international asset allocation. J. Portfolio Manage., vol. 9, 11-21.

Yallup, P.J. 1982. A study of possible gains from international investment and the stationarity of inter-country correlation coefficients: a comment. J. Bus. Fin. Acc., vol.9, 109-115. 